\section{Transition metal availability to speleothems controlled by organic binding ligands}

A. Hartland ${ }^{1 *}$, R. Zitoun ${ }^{2}$

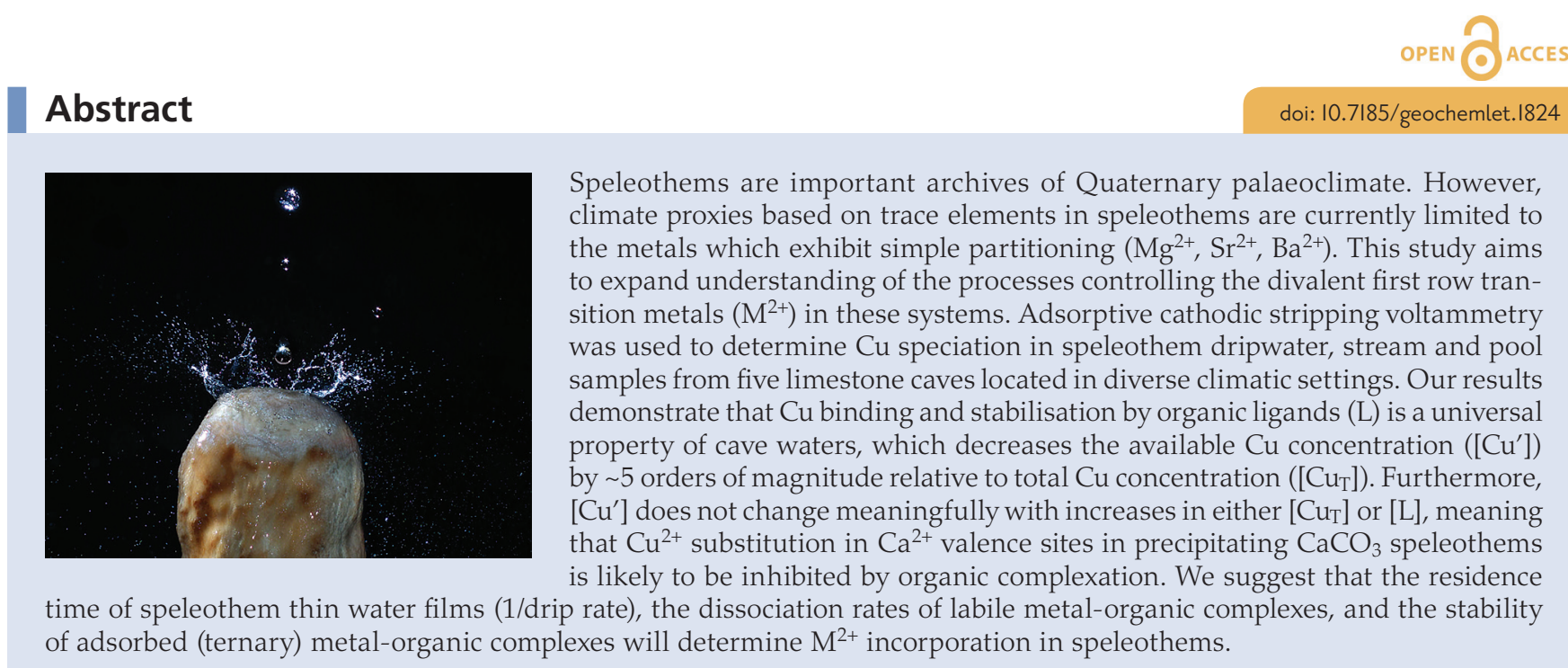

Received 18 July 2018 | Accepted 3 September 2018 | Published 27 September 2018

\section{Introduction}

The pervasiveness of natural organic matter (NOM) in aquatic systems has been established for decades (Oliver et al., 1983; Filella, 2009). Equally well established is the interaction between trace metals and NOM ligands, which dominates metal speciation and bioavailability in aquatic environments with $\mathrm{pH}$ values typical of cave waters $(\mathrm{pH} \sim 8)$ (Tipping and Hurley, 1992).

It is possible to classify different metals according to their NOM binding affinity, with $\mathrm{Cu}$ and $\mathrm{Ni}$ showing particularly high binding strength among the transition metals (Warnken et al., 2007; Levy et al., 2012). The interaction between $\mathrm{Cu}$, ligands and inorganic ions in water can be summarised using the following mass balance (charges omitted for simplicity with exception of $\mathrm{Cu}^{2+}$ ):

$$
\begin{array}{cc}
{\left[\mathrm{Cu}_{\mathrm{T}}\right]=[\mathrm{CuL}]+\left[\mathrm{Cu}^{\prime}\right]} & \text { Eq. } 1 \\
{\left[\mathrm{Cu}^{\prime}\right]=\left[\mathrm{Cu}^{2+}\right]+\left[\mathrm{CuX}_{\mathrm{IN}}\right]} & \text { Eq. } 2
\end{array}
$$

Where [ ] denotes concentration, $\mathrm{Cu}_{\mathrm{T}}$ is the total copper in the analysis (no differentiation based on filtration, majority of samples in this study were unfiltered), $\mathrm{CuL}$ is the $\mathrm{Cu}$ fraction bound by organic ligands, $\mathrm{Cu}^{2+}$ is the hydrated 'free' form of the copper cation, $\mathrm{CuX}_{\mathrm{IN}}$ is the fraction of copper held in simple inorganic complexes (e.g., $\mathrm{CuCl}^{+}, \mathrm{CuHCO}_{3}^{+}$etc), and
$\mathrm{Cu}^{\prime}$ is the 'available copper' calculated as the sum of $\mathrm{Cu}^{2+}$ and $\mathrm{CuX}_{\text {IN }}$. $\mathrm{CuX} \mathrm{X}_{\text {IN }}$ is considered to be labile because the stability of inorganic transition metal complexes (which dissociate rapidly in the presence of a suitable sink) is much lower than metal-organic complexes (which dissociate much more slowly (Shafaei Arvajeh et al., 2013)).

The transport of metals by colloidal and dissolved NOM has been shown to be important in shallow near surface systems (Hartland et al., 2012). However, the aforementioned research has to some extent 'muddied the waters', with the role of NOM often becoming equated with soil flushing in the speleothem literature and not being recognised for its pervasive influence both in metal transport and metal distribution between solution and crystal.

While organic complexation is very important for transmission of metals in karst aquifers (Hartland et al., 2011), strong binding of metals by NOM also creates an 'aqueous sink' for divalent metal ions which is likely to inhibit $\mathrm{M}^{2+}$ substitution for $\mathrm{Ca}^{2+}$ in calcite lattice sites (Hartland et al., 2014). Thus, it is not appropriate to interpret the changing concentration of transition metals in dripwaters (and by extension speleothems) in terms of simple partitioning (as is routinely and correctly done with regard to the alkaline earth metals (Huang and Fairchild, 2001; Day and Henderson, 2013)).

\footnotetext{
1. Environmental Research Institute, School of Science, University of Waikato, Private Bag 3105, Hamilton 3240, New Zealand

2. Department of Chemistry and Centre for Trace Element Analysis, University of Otago, PO Box 56, Union Place, Dunedin, New Zealand
} Corresponding author (email: adam.hartland@waikato.ac.nz) 
The aim of this paper is to establish the fact that metal binding by NOM ligands in the waters that form speleothems dictates that the activity of $\left[\mathrm{M}^{\prime}\right] \ll\left[\mathrm{M}_{\mathrm{T}}\right]$; and therefore, the formation of $\mathrm{CaCO}_{3} / \mathrm{Ca}(\mathrm{M}) \mathrm{CO}_{3}$ solid solutions cannot be treated using partition coefficients unless the role of organic ligands is properly accounted for (Fairchild et al., 2012). As a model system we use $\mathrm{Cu}$, which has a strong binding affinity for NOM, to demonstrate this point and present a new hypothesis on the climatic significance of transition metal variations in speleothems.

\section{Methods and Materials}

Study sites. Samples of cave water were collected in acid washed, low density polyethylene (LDPE) bottles (Hartland et al., 2011) direct from active speleothem-forming drip points (including one pool and one stream sample) in five New Zealand caves. The caves were located across a latitudinal gradient: $38^{\circ} \mathrm{S}$ Waipuna Cave $(\mathrm{n}=24 ; 21$ drip samples, 3 stream samples), Waitomo, subtropical podocarp forest; $40^{\circ} \mathrm{S}$ Nettlebed Cave $(n=2)$ and Hodges Creek Cave $(n=6)$, temperate Beech forest; and $45^{\circ} \mathrm{S}$ Calcite Cave $(\mathrm{n}=2)$ and Dave's Cave ( $\mathrm{n}=3$; 2 drips, 1 pool), Mt Luxmore, Fiordland, alpine tussock grassland. Unless otherwise noted drip samples were collected from actively-depositing stalactites. With the exception of Nettlebed, New Zealand's deepest cave (889 m), developed in Ordovician marble, all other caves are developed in Oligocene shallow marine limestone. Upon collection, water samples were chilled to $<4{ }^{\circ} \mathrm{C}$, then frozen (within 48 hours) and stored at $-4{ }^{\circ} \mathrm{C}$ prior to analysis.

Experimental. 1. Adsorptive cathodic stripping voltammetry (AdCSV). To determine $\mathrm{Cu}$ speciation parameters Adsorptive Cathodic Stripping Voltammetry (AdCSV) with salicylaldoxime (SA) was used as the synthetic complexing agent (Lucia et al., 1994). Prior to analysis, each unfiltered sample was thawed at $4{ }^{\circ} \mathrm{C}$ overnight and brought up to room temperature $\left(22^{\circ} \mathrm{C} \pm 1\right)$. For the $\mathrm{Cu}$ ligand titrations, 12 aliquots ( $4 \mathrm{~mL}$ each) of each sample were separately transferred into acid washed and pre-conditioned Teflon vials. Afterwards, $15 \mu \mathrm{L}$ of $3 \mathrm{M} \mathrm{KCl}$ (Metrohm), used as a supporting electrolyte (final sample salinity of $0.08 \mathrm{ppt}$ ), and $100 \mu \mathrm{L}$ of $1 \mathrm{M}$ EPPS buffer (Sigma Aldrich, stock solution $1 \mathrm{M}$ in Milli-Q adjusted to $\mathrm{pH} 8$ with $\mathrm{NaOH}$ ) were added to each sample - all titrations reported here were performed at a $\mathrm{pH}$ of $8.0 \pm 0.2$, making direct comparison of $\mathrm{Cu}$ speciation parameters possible (Sander et al., 2005). This step was followed by increasing $\mathrm{Cu}$ additions (ranging from 0 to $300 \mathrm{nM}$ ), calculated as a geometrically spaced series (i.e. logarithmic scale) (Garnier et al., 2004), of a known Cu standard (Fisher Scientific, prepared by dilution of a $15.74 \mathrm{mM}$ atomic absorption $\mathrm{Cu}$ standard in $1 \%$ quartz distilled $\mathrm{HCl}$ ) to the 12 aliquots (Sander et al., 2007). A 20 min equilibration period was then implemented to allow the $\mathrm{Cu}$ to bind with the natural organic ligands present in solution. Subsequently, SA (Acros Organics; SA: $98 \%$ ) was added to the aliquots at a final concentration of $5 \mu \mathrm{M}$. Finally, samples were left to equilibrate for a minimum of 12 hours, which was found to result in stable Cu-SA peaks (Sander et al., 2007). Once equilibrated, samples were analysed by AdCSV using a Metrohm 663 VA stand connected to a PGSTAT10 (Eco Chemie) potentiostat interfaced with GPES v4.9 software. The three electrode configuration of the system included a hanging mercury drop electrode (HMDE) as the working electrode, an $\mathrm{Ag}|\mathrm{AgCl}| 3 \mathrm{M} \mathrm{KCl}$ reference electrode, and a platinum counter electrode. The system was operated in differential pulse mode at room temperature. The deposition on a medium-sized $\mathrm{Hg}$ drop was set at $-0.15 \mathrm{~V}$ for 30-180 s (deposition times varied for different samples according to their initial $\left.\left[\mathrm{Cu}_{\mathrm{T}}\right]\right)$, followed by a $5 \mathrm{~s}$ equilibrium time and a cathodic scan from -0.15 to $-0.6 \mathrm{~V}$ at $20 \mathrm{mV} / \mathrm{s}$. The potential step size was $5 \mathrm{mV}$, the modulation time $0.05 \mathrm{~s}$, the interval time $0.1 \mathrm{~s}$, and the differential pulse amplitude was $25 \mathrm{mV}$.

Prior to the AdCSV measurement each sample was de-aerated for $120 \mathrm{~s}$ with $\mathrm{O}_{2}$-free $\mathrm{N}_{2}$. Measurements were carried out in triplicate, using a freshly generated mercury drop for each replicate. If sample volume was sufficient, samples were run in duplicate (unfiltered) and/or were filtered (0.2 $\mu \mathrm{m}$; using an acid washed syringe and an acrodisc filter). All sample handling and electrochemical measurements were conducted inside a clean air bench following trace metal clean procedures (Sander et al., 2005; Powell, 2015).

2. Calculation of $\mathrm{Cu}$ speciation parameters. After completion of the titration, the ProMCC software (Omanovic et al., 2010) was used to calculate conditional formation constants (K), Cu-binding ligand concentrations ([L]), and $\left[\mathrm{Cu}^{\prime}\right]$ (sum of $\left[\mathrm{Cu}^{2+}\right]$ and $\left[\mathrm{CuX}{ }_{\text {IN }}\right]$ ) of each solution. Conditional stability constants (input data for ProMCC) of

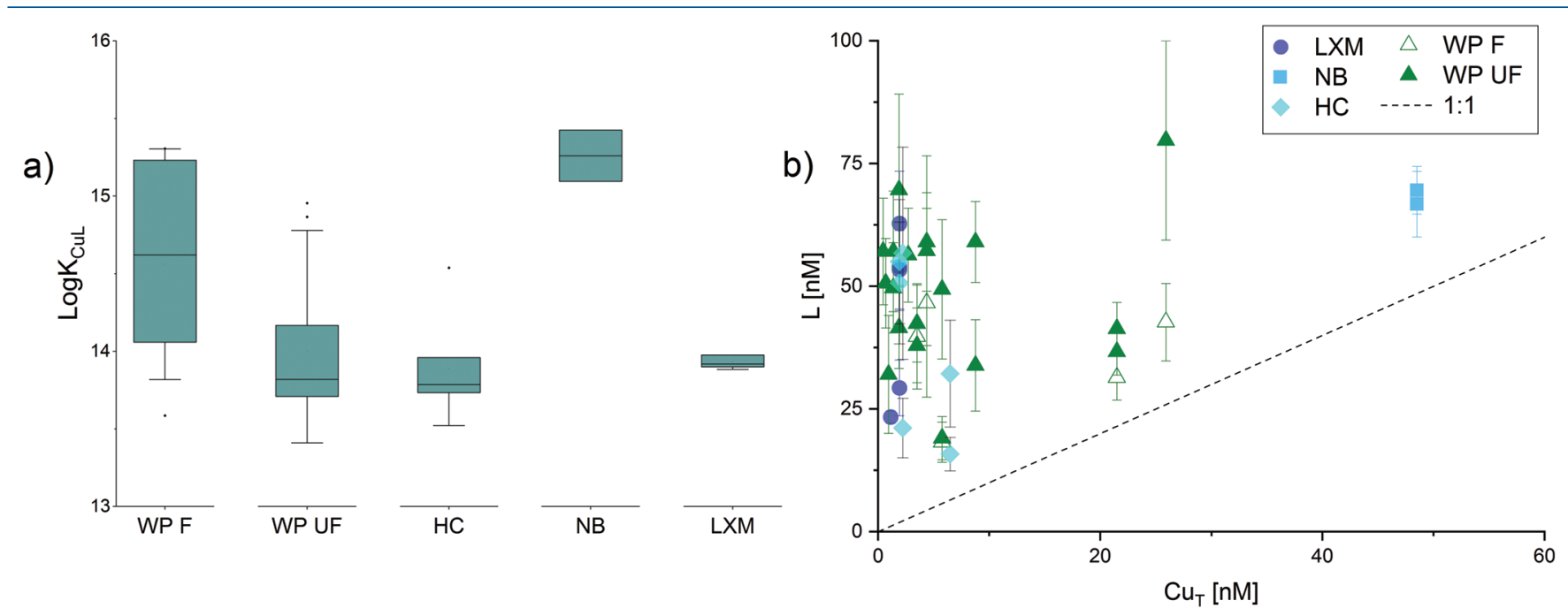

Figure 1 (a) Box plots of conditional stability constants (log $\mathrm{K}_{\mathrm{CuL}}$ ) of CuL complexes in cave samples. Values calculated using ProMCC (Omanovic et al., 2015). Error bars are 1 standard deviation. (b) Correlation between the total Cu concentration ([CUT]) and corresponding $\mathrm{Cu}$ ligand concentration. For all samples which plot above the 1:1 dashed diagonal line, one can assume that all available Cu is strongly complexed to organic ligands. Vertical error bars represent the fitting error in $\left[L_{1}\right]$. WP $=$ Waipuna Cave $(n=24), F=$ filtered, $U F=u n f i l t e r e d$; HC = Hodges Creek Cave $(n=6) ; N B=$ Nettlebed Cave $(n=2) ; L X M=M t$ Luxmore Caves; Daves Cave $(n=3)$ and Calcite Cave $(n=2)$. 
the CuSAx-complex of the samples were adjusted according to the approach of Lucia et al. (1994). The inorganic side reaction coefficient ( $\alpha$-Cu-inorg) for $\mathrm{Cu}$ was adjusted for each sample separately using Visual MINTEQ 3.0 with set input variables: $\mathrm{pH}$ of 8.0 , a temperature of $21^{\circ} \mathrm{C}$, and measured concentrations of $\mathrm{Cu}, \mathrm{Ca}, \mathrm{Mg}, \mathrm{K}, \mathrm{Na}, \mathrm{Cl}, \mathrm{SO}_{4}, \mathrm{HCO}_{3}$ and $\mathrm{CO}_{3}$. Potential inaccuracy introduced by using adjusted conditional constants for CuSA and inorganic side reaction coefficients are assumed to be fully within experimental uncertainty.

\section{Results and Discussion}

For all titrations, the fitted data could be adequately explained by a one ligand model. This modelling does not inform ligand composition, beyond identifying the stability of the metalorganic complexes (see below). Titrations demonstrated the presence of a strong organic ligand class (i.e. $\mathrm{L}_{1}$ ), ranging from 15.8 - $79.7 \mathrm{nM}$, with $\mathrm{Cu}$-binding capacities of $\log \mathrm{K}_{\mathrm{CuL}}$ 13.4 - 15.4. Ligand concentrations ranged from as low as $\left[\mathrm{L}_{1}\right]=15.8 \pm 3.4 \mathrm{nM}$ (Hodges Creek Cave), to $79.7 \pm 20.3 \mathrm{nM}$ (Waipuna Cave). Ligand concentrations differed between unfiltered and filtered $(0.2 \mu \mathrm{m})$ Waipuna Cave samples, with filtered samples usually having lower $\left[\mathrm{L}_{1}\right]$ and higher $\log \mathrm{K}_{\mathrm{CuL}}$ than unfiltered ones (Fig. 1a). This indicates the presence of organic ligands in the size fraction above $0.2 \mu \mathrm{m}$, consistent with previous studies which identified $\mathrm{Cu}$ associated with coarse colloidal NOM in cave systems (Hartland et al., 2011, 2012). Further, the ligand concentrations were always in excess of the total $\mathrm{Cu}$ concentrations $\left(\left[\mathrm{Cu}_{\mathrm{T}}\right]\right)$ (Fig. $\left.1 \mathrm{~b}\right)$, indicating that all $\mathrm{Cu}$ was present in complexes with organic ligands.

Conditional stability constants $\left(\log \mathrm{K}_{\mathrm{CuL}}\right)$ ranged from as low as $13.4 \pm 0.2$ from Waipuna Cave to $15.4 \pm 0.2$ in samples from Nettlebed Cave. The determined stability constants indicate $\mathrm{Cu}$ complexation with organic ligands, such as thiols, carboxylic acids, hydroxyl and amine functional groups, which have very high stability constants $\left(\log \mathrm{K}_{\mathrm{CuL}}\right.$ of 14-16) (Sander and Koschinsky, 2011). Further, $\log K_{\mathrm{CuL}}$ values generally increased between unfiltered and filtered samples, which suggests that $\mathrm{Cu}$ complexes with nano-scale organic ligands are slightly more stable than $\mathrm{Cu}$ complexes with colloids $>0.2 \mu \mathrm{m}$ (Hartland et al., 2012).

Available $\mathrm{Cu}$ concentrations in solution (sum of $\left[\mathrm{Cu}^{2+}\right]$ and $\left[\mathrm{CuX} \mathrm{IN}_{\mathrm{IN}}\right]$ ) were low, ranging from $11.9 \mathrm{fM}$ to $34.5 \mathrm{pM}$, some five orders of magnitude lower than $\left[\mathrm{Cu}_{\mathrm{T}}\right]$ (Fig. 2). Indeed, $\left[\mathrm{Cu}^{\prime}\right]$ only increased weakly with higher $\left[\mathrm{Cu}_{\mathrm{T}}\right]$, indicating that the scarcity of $\mathrm{Cu}^{2+}$ due to the action of binding ligands is a universal feature of cave dripwaters. Aside from the significance of this finding for trace element signals in speleothems (Fairchild et al., 2012), this finding also has significance for geomicrobiology because at biologically available $\mathrm{Cu}$ concentrations (Zhao et al., 2016) below $10^{-15} \mathrm{M}, \mathrm{Cu}$ is an inhibitor (e.g., microbial activity/growth) for some marine microorganisms (Sunda and Huntsman, 1995). We also note that [L] was uncorrelated with the total organic carbon (TOC) concentration - dripwater TOC mainly correlates with soilderived organic matter based on numerous fluorescence studies (Liao et al., 2018) - in the samples (Fig. S-1), and therefore cannot exclude the possibility that microbes in cave systems secrete ligands in order to regulate copper bioavailability (Peña et al., 1998), thereby contributing to the pool of $\mathrm{Cu}$ binding ligands in the system.

From a review of the literature, the evidence suggests that $\mathrm{Cu}^{2+}$ adsorption to calcite is favoured (Elzinga and Reeder, 2002) but inhibited by formation of solution complexes with organic ligands (Lee et al., 2005), i.e. the 'aqueous sink' (Fig. 3). Previous experimental work (Lee et al., 2005) also indicates that ternary (metal-organic) complexes (Fein, 2002) at the calcite surface have lower stabilities than non-ternary complexes,

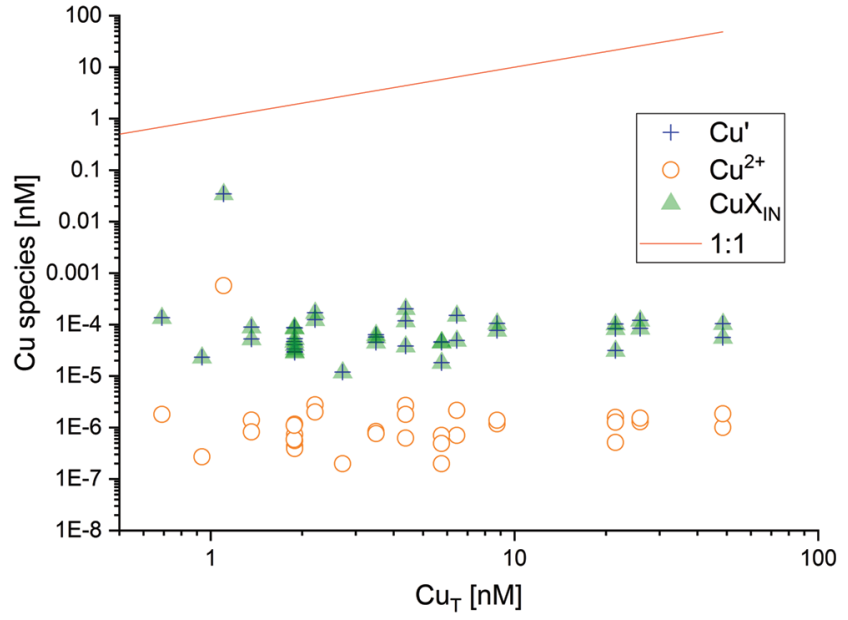

Figure 2 Available $\left(\mathrm{Cu}^{\prime}\right)$, inorganic $\left(\mathrm{CuX}{ }_{I N}\right)$ and free $\left(\mathrm{Cu}^{2+}\right)$ copper concentrations plotted against $\left[\mathrm{Cu}_{\mathrm{T}}\right]$ in cave samples calculated using ProMCC (Omanovit et al., 2015). [Cu'] are consistently low despite widely varying $\left[\mathrm{Cu}_{\mathrm{T}}\right]$ demonstrating the dominant influence of organic ligands in these samples.

and this is supported by empirical evidence showing large increases in the metal/NOM ratio between dripwaters and speleothems (Hartland et al., 2014).

If we accept that the inorganic pathway (i.e. $\mathrm{Cu}^{2+}$ substitution) is the dominant mechanism for $\mathrm{Cu}$ incorporation in speleothems, it follows that under conditions of continuous calcite precipitation, $\mathrm{Cu}^{2+}$ adsorption to calcite will proceed at the rate dictated by the kinetics of CuL dissociation (Warnken et al., 2007). We can expect that the rapid adsorption (Elzinga and Reeder, 2002; Lee et al., 2005) of newly dissociated $\mathrm{Cu}^{2+}$ to the calcite surface (i.e. the 'solid phase sink') will further drive this dissociation process, likely profoundly changing the resulting stable metal isotope fractionation compared with inorganic laboratory experiments (Schott et al., 2014) (Fig. 3). With the exception of sub-aqueous calcite deposition (typically characterised by very long water residence times), the time available for dissociation is the residence time of the crystallising fluid, which may be approximated by the interval between drips. This opens the possibility of reconstructing the palaeo-discharge of speleothem dripwaters based on the metal accumulation (and metal isotope fractionation) patterns of speleothems (if the dissociation rate constants of metalorganic complexes and fractionation factors can be determined (Fig. 3)).

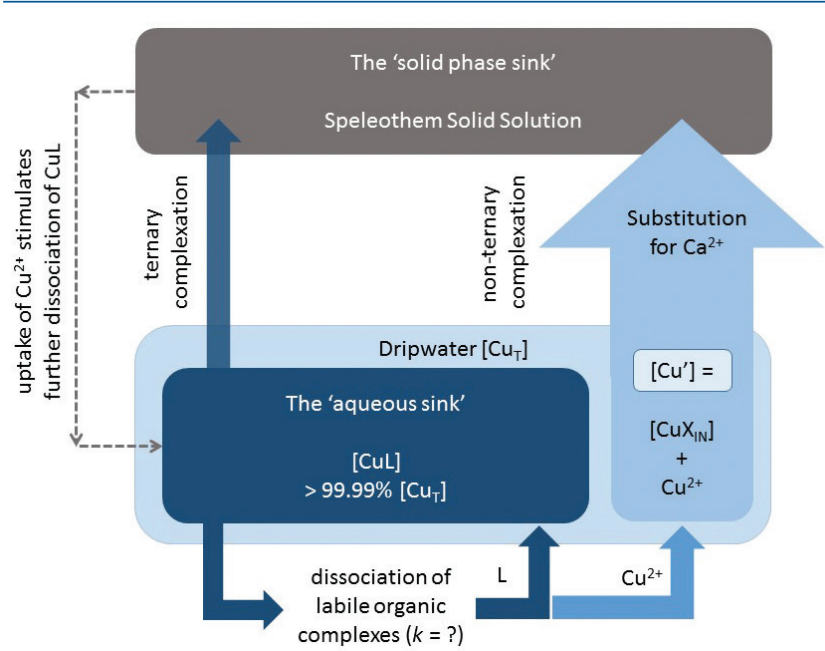

Figure 3 Conceptual diagram illustrating the influence of $\mathrm{Cu}$ ligands on the incorporation of $\mathrm{Cu}$ in speleothems. 


\section{Conclusions}

We have shown that dissolved ligands $(<0.2 \mu \mathrm{m})$ are the primary agents controlling the speciation of $\mathrm{Cu}$ in speleothem-forming cave waters. Indeed, complexation by strong binding ligands drives consistently low concentrations of [Cu'] despite widely varying $\left[\mathrm{Cu}_{\mathrm{T}}\right]$. We argue that dominant organic complexation of divalent transition metals $\left(\right.$ e.g., $\mathrm{Ni}^{2+}, \mathrm{Co}^{2+}, \mathrm{Cu}^{2+}$ and $\left.\mathrm{Zn}^{2+}\right)$ and other metals able to bind to organic ligands (e.g., $\mathrm{Cd}^{2+}$ and $\left.\mathrm{Pb}^{2+}\right)$ in the 'aqueous sink' leads to a range of signals in speleothems controlled by the dissociation rates of these complexes, the residence time of the dripwaters (1/drip rate) and the compatibility of $\mathrm{M}^{2+}$ in lattice valence sites. Through this study we aim to increase awareness in the speleothem community of the central importance of metal complexation by organic ligands for understanding trace element signals in speleothems. Future research should aim at understanding the significance of these processes for speleothem palaeoclimate records, and the geomicrobiology of karst environments.

\section{Acknowledgements}

This research was enabled by Marsden Fund grant (UOW1403) and Rutherford Discovery Fellowship (RDF-UOW1601) to AH., and a PhD scholarship from the University of Otago to RZ. Graphical abstract image provided by Garry K. Smith.

Editor: Eric H. Oelkers

\section{Additional Information}

Supplementary Information accompanies this letter at http:// www.geochemicalperspectivesletters.org/article1824.

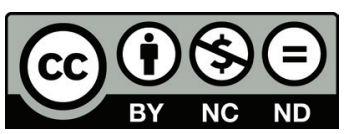

This work is distributed under the Creative Commons Attribution Non-Commercial No-Derivatives 4.0 License, which permits unrestricted distribution provided the original author and source are credited. The material may not be adapted (remixed, transformed or built upon) or used for commercial purposes without written permission from the author. Additional information is available at http://www.geochemicalperspectivesletters.org/ copyright-and-permissions.

Cite this letter as: Hartland, A., Zitoun, R. (2018) Transition metal availability to speleothems controlled by organic binding ligands. Geochem. Persp. Let. 8, 22-25.

\section{References}

Day, C.C., Henderson, G.M. (2013) Controls on trace-element partitioning in cave-analogue calcite. Geochimica et Cosmochimica Acta 120, 612-627.

ElZINGA, E.J., ReEDER, R.J. (2002) X-ray absorption spectroscopy study of $\mathrm{Cu} 2+$ and $\mathrm{Zn} 2+$ adsorption complexes at the calcite surface: Implications for site-specific metal incorporation preferences during calcite crystal growth. Geochimica et Cosmochimica Acta 66, 3943-3954.

Fairchild, I.J., Baker, A., AsRat, A., Domínguez-Villar, D., GunN, J., Hartland, A., Lowe, D. (2012) Speleothem Science: From Process to Past Environments. Wiley-Blackwell, Chichester.

FEIN, J.B. (2002) The effects of ternary surface complexes on the adsorption of metal cations and organic acids onto mineral surfaces. In: Hellmann, R., Wood, S.A. (Eds.) Water-Rock Interactions, Ore Deposits and Environmental Geochemistry: A Tribute to David A. Crerar. The Geochemical Society, Special Publication No. 7, 365-378.

FILELLA, M. (2009) Freshwaters: Which NOM matters? Environmental Chemistry Letters 7, 21-35.
Garnier, C., Pižeta, I., Mounier, S., Benaïm, J.Y., Branica, M. (2004) Influence of the type of titration and of data treatment methods on metal complexing parameters determination of single and multi-ligand systems measured by stripping voltammetry. Analytica Chimica Acta 505, 263-275

Hartland, A., Fairchild, I.J., Lead, J.R., Zhang, H., BaAlousha, M. (2011) Size, speciation and lability of NOM-metal complexes in hyperalkaline cave dripwater. Geochimica et Cosmochimica Acta 75, 7533-7551.

Hartland, A., Fairchild, I.J., Lead, J.R., Borsato, A., Baker, A., FrisiA, S., BAALOUSHA, M. (2012) From soil to cave: Transport of trace metals by natural organic matter in karst dripwaters. Chemical Geology 304-305, 68-82.

Hartland, A., Fairchild, I.J., Müller, W., Dominguez-Villar, D. (2014) Preservation of NOM-metal complexes in a modern hyperalkaline stalagmite: Implications for speleothem trace element geochemistry. Geochimica et Cosmochimica Acta 128, 29-43.

HuANG, Y., FAIRCHILD, I.J. (2001) Partitioning of Sr2+ and Mg2+ into calcite under karst-analogue experimental conditions. Geochimica et Cosmochimica Acta 65, 47-62.

Liao, J., Hu, C., Wang, M., Li, X., Ruan, J., Zhu, Y., Fairchild, I.J., HARTLAND, A. (2018) Assessing acid rain and climate effects on the temporal variation of dissolved organic matter in the unsaturated zone of a karstic system from southern China. Journal of Hydrology 556, 475-487.

LeE, Y.J., ElzingA, E.J., ReEdeR, R.J. (2005) Cu(II) adsorption at the calcitewater interface in the presence of natural organic matter: Kinetic studies and molecular-scale characterization. Geochimica et Cosmochimica Acta 69, 49-61.

Levy, J.L., Zhang, H., Davison, W., Galceran, I., Puy, J. (2012) Kinetic signatures of metals in the presence of suwannee river fulvic acid. Environmental Science and Technology 46, 3335-3342.

Lucia, M., CAmpos, A.M., VAN DEN BeRG, C.M.G. (1994) Determination of copper complexation in sea water by cathodic stripping voltammetry and ligand competition with salicylaldoxime. Analytica Chimica Acta 284, 481-496.

Oliver, B.G., Thurman, E.M., Malcolm, R.L. (1983) The contribution of humic substances to the acidity of colored natural waters. Geochimica et Cosmochimica Acta 47, 2031-2035.

Omanović, D., Garnier, C., Louis, Y., Lenoble, V., Mounier, S., PIŽETA, I. (2010) Significance of data treatment and experimental setup on the determination of copper complexing parameters by anodic stripping voltammetry. Analytica Chimica Acta 664, 136-143.

Omanović, D., Garnier, C., PiŽEtaA, I. (2015) ProMCC software. https:// sites.google.com/site/mccprosece/download.

PeÑA, M.M.O., KocH, K.A., Thiele, D.J. (1998) Dynamic Regulation of Copper Uptake and Detoxification Genes in Saccharomyces cerevisiae. Molecular and Cellular Biology 18, 2514-2523

Powell, Z. (2015) Voltammetric Studies on the Stabilisation of Dissolved Copper in Hydrothermal Vent Fluids. PhD Thesis, University of Otago. http://hdl.handle.net/10523/5413.

SAnder, S., Kim, J.P., Anderson, B., Hunter, K.A. (2005) Effect of UVB irradiation on $\mathrm{Cu} 2+-$-binding organic ligands and $\mathrm{Cu} 2+$ speciation in alpine lake waters of New Zealand. Environmental Chemistry 2, 56-62.

SANDER, S.G., KOSCHINSKY, A. (2011) Metal flux from hydrothermal vents increased by organic complexation. Nature Geoscience 4, 145-150.

SAnder, S.G., Koschinsky, A., Massoth, G., Stott, M., Hunter, K.A. (2007) Organic complexation of copper in deep-sea hydrothermal vent systems. Environmental Chemistry 4, 81-89.

Schott, J., Mavromatis, M., GonzÁlez-GonzÁlez, A., Oelkers, E.H. (2014) Kinetic and thermodynamic controls of divalent metals isotope composition in carbonate: Experimental investigations and applications. Procedia Earth and Planetary Science 10, 168-172.

Shafaei Arvajeh, M.R., Lehto, N., Garmo, Ø.A.,Zhang, H. (2013) Kinetic studies of $\mathrm{Ni}$ organic complexes using diffusive gradients in thin films (DGT) with double binding layers and a dynamic numerical model. Environmental Science and Technology 47, 463-470.

Sunda, W.G., HuntSMAN, S.A. (1995) Regulation of copper concentration in the oceanic nutricline by phytoplankton uptake and regeneration cycles. Limnology and Oceanography 40, 132-137.

Tipping, E., Hurley, M.A. (1992) A unifying model of cation binding by humic substances. Geochimica et Cosmochimica Acta 56, 3627-3641.

Warnken, K.W., Davison, W., Zhang, H., Galceran, J., Puy, J. (2007) In situ measurements of metal complex exchange kinetics in freshwater. Environmental Science and Technology 41, 3179-3185.

Zhao, C., Campbell, P.G.C., Wilkinson, K.J. (2016) When are metal complexes bioavailable? Environmental Chemistry 13, 425-433. 